\title{
4 Karen
}

\section{A House}

Each time I watch the movie Out of Africa, I get swept up in the sheer beauty of it all - the scenery, the sets, the music and the love story. It's hard to believe it was filmed in 1985 because all these years later, it feels timeless. I still love Karen Blixen's house just as much as I did the first time I saw it. ${ }^{1}$

Nairobi offers many interesting sights for movie site tourists. But one of these attractions outshines them all: the house in which Karen Blixen lived. It is a one-storey bungalow with a shady porch, large doors that allow fresh breezes to sweep into the living room, and private rooms overlooking the rolling Ngong Hills. The house was built in 1911 by the Swedish architect Åke Sjögren, whose masterpiece it has remained until today. This is partly due to the fact that nobody seems to remember any other house ever having been built by this man, and partly due to the fact that even if he had built another, nobody would care. For the sheer beauty, scenery and love that inhabit this house are, as writer Julia Sweeten points out, hard to exceed; this is not an ordinary house, it is a romantic house. A house built by an enigmatic architect, by the Swedish sphinx of architects, only to become the home of timeless love just five years or so after its completion. And it has remained this way, in spite of changing owners and inhabitants in later years.

The house is located 16 kilometres from Nairobi's city centre, and can be reached by taxi or bus along either the Ngong or Langata roads. The little journey out of town is one of the things that are considered highlights of a visit to Nairobi, offering impressions of an undying past. One can not only drive out there, but one can actually enter this house, this home of love and romance. Since 1986 the bungalow has contained a museum dedicated to Karen Blixen. Surrounding its spacious grounds, there is a nature trail into virgin forest as well as the surrounding gardens (over 100 plant species), and there are birds (116 species), butterflies and squirrels that can be watched. The museum is open daily from $8 \mathrm{am}$ to $5 \mathrm{pm}$ and charges KSH 200 (approx. 1,80\$/1,30 Pound) per person (residents)/ KSH 1000 (non-residents). It can be visited on guided tours only, which are offered throughout the day. The souvenir shop offers books by Karen Blixen, African beadwork and wood carvings, as well as DVDs of the 
movie that was inspired by one of her books. The guestbook contains many favourable comments, mostly by American and Danish visitors.

Julia Sweeten, who writes about houses, has explored the real Karen Blixen house in more detail. Another 'real' Karen Blixen house once stood nearby, and was the previous home of the widow of Jomo Kenyatta. It must have been overgrown by ivy and other plants, because Sweeten mentions that, in order to be turned into Blixen's 'house', it needed to be cleared of vegetation. After this, some architectural additions were made in order to make it more Åke Sjögren-like, and different vegetation had to be planted. Then furniture and fresh paint were added, making it a lovely house where, finally, the 'newly-wed Blixens' could move in. But matrimonial bliss didn't last long because Karen contracted syphilis from her husband, the 'Baron'. A pilot then flew by, dressed in white, washed her hair in a portable hair-washer, and they fell in love. This was true love, not syphilitic love, and Karen enjoyed some newly found freedom which she expressed by wearing complicated breeches instead of complicated gowns. She and the White pilot roamed through savannas and wildernesses, living rooms and porches. Unfortunately, this was not meant to last forever, because the pilot wanted to fly, and died in a terrible plane accident out there in the 'African vastness', where his remains lie until this day. $x$.

Sydney Pollack's film, based on Blixen's book, premiered in 1985 and remains well known and much loved, especially by European and American audiences. Sweeten's reminiscence of the film's setting, namely the home of its main character (the HOUSE), meticulously traces all the architectural modifications and preparations that were needed to create the ambience of colonial life that obviously enthused audiences immediately and continues to do so. And so, an old dairy turned into timeless scenery for an anachronistic story, Hollywood plastic, consumable and imitable.

While the actual Karen Blixen house stood nearby, a bit neglected and occupied by a governmental training facility and therefore not available as a site to make the film, its revenant became a powerful yet elusively immaterial icon of what audiences elsewhere expected of Africa. As the simulacrum of Blixen's house and life re-created and affirmed imaginations of colonial image politics, spaces and power relations, new interest in the writer emerged. Within a few months, a Danish woman, a member of a privileged social group of urban bourgeoisie and a settler colonist, was turned into a symbol of anti-bourgeois libertinage, the fight for women's rights and the subversion of colonial regimes of bodies and spaces. The beautiful style of her writing, her extraordinary appearance and her former fame as a mid-century New York intellectual idol provided sufficient means for such a popular resurrection. And soon the real house was resurrected as well. Mbogani, as it is called, was finally bought by the Danish state in the early 1960s (after Karen's death), and was subsequently 
presented to the Kenyan state as a gift commemorating decolonization. Colonial memories, lest we forget. This too won't pass and, fittingly, the building and its surrounding grounds were used to host a training centre for domestic workers - a school for servants. Afterwards came decay. Imperial debris in the midst of more colonial rubble.

The interesting thing is that the romanticization of this place, the construction of a very particular semiotic and emotional landscape, did not happen until the property was discovered as the antagonistic counterpart of the invented romantic home, the furnished and decorated movie site that enchanted everybody with its colonial props. With the help of a couple of thousand US dollars donated and invested by Universal Films, imperial debris was remade into its own simulacrum, a heritage site that

features rooms designed in both the original decor and with props from the 1985 film. The grounds, which feature original equipment from the coffee farm, are also available for touring. The grounds of the museum are available to rent for weddings, corporate functions, and other events. ${ }^{2}$

What can be visited now may also be used as a site of still more heritage practices - family heritaging, remembering a wedding or a reunion, might be linked to a place where imagined characters engaged in imagined romance, surrounded by imagined people in an imagined Africa: There, everything seems blurred (Figure 4.1). Individual, personal heritage practices intertwine with practices of the colonial imagination. Blixen, as a

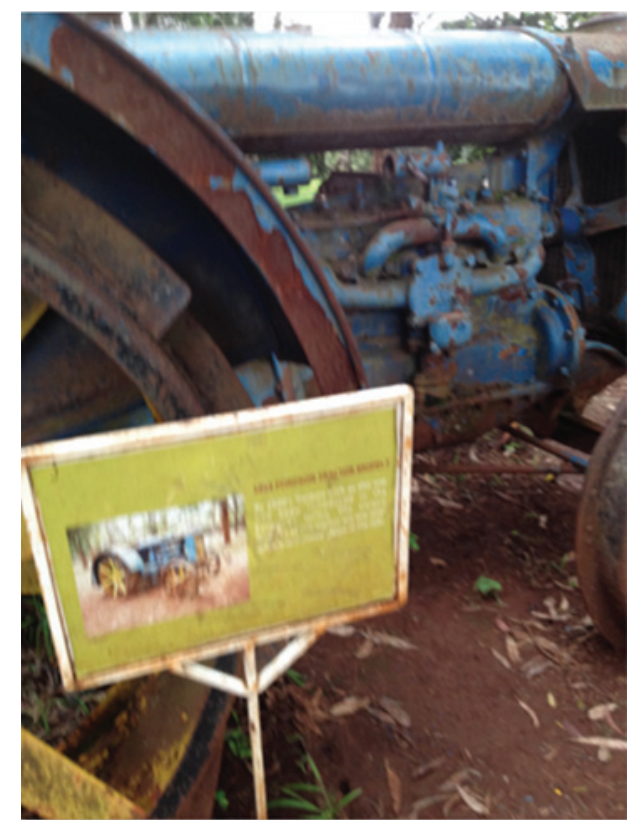

Figure 4.1 A vague tractor 
destination for heritage tourism, here emerges out of a film set again and again, each time a blogger posts a series of images from the film, each time phantasies of love and safari trigger holiday plans, each time a travel guide offers a special suggestion. The actual building turns into a simulacrum itself, by being constructed as an emotional landscape that provides options for the heritage practices of diverse people and for diverse aims. Yet these largely seem to affirm heteronormative and neocolonial concepts of partnership, hospitality, entangled history, bodies and texts.

\section{A Woman}

Visitors appear to be less interested in a critical view of the colonial history of the place than in an affirmative performance of colonial melancholy. The visitors' commentaries in the museum's guestbook and the comments on webpages, as well as ways of consuming the site itself, reveal how closely personal experiences of the visit are connected to the stereotyped images presented in the film: of the colonial Other, of women, of bodies. Visitors take selfies wearing safari hats, sit on the manicured lawn on green plastic chairs arranged in circles and listen to a guide's explanations, or buy commemorative objects in the shop. Most seem to accept what is told them in the bits of text that are offered by the guides and on the small signboards mounted on benches and plants.

Notes in a field notebook:

This is the home of a woman whose books belong to Kenya's rich heritage, this deserves a visit, requires respect, elicits love.

The person whose spirit is still there (in the house) was wonderful.

She looked different.

She was different.

She talked to her Kikuyu servant as if they were coequal, coeval.

She called him when she needed to and he called her Memsahib.

The dresses are still there, too.

Costumes donated by the film company, or the director.

Doesn't matter.

But yet - to wear this: be this.

No critical question about colonial continuities, about what she had actually written in these books on Africa, or what others had written, Hemingway on the bedside cabinet.

Will read that tonight. - Noble prize winner. - Said she should have won. - Next time Steinbeck won. (Like him a lot.)

What did she write. Books on women, mostly. 
A women's writer.

A writer who wrote about women, or for women, or on behalf of women? Very thin, eyes so big.

But the pilot. Chest hair coming out of a white shirt, unbuttoned.

Her writings sit there on a bookshelf. A large cabinet, rather. Filled with books. Translated into all the world's languages. Languages that count, at least. Not Gikuyu. Danish, German, Swahili maybe. The books must not be taken out; they are exhibited reliquiae. All she left behind. She never came back so that's all she left for them.

Them? Whom?

In the kitchen there is something we can buy. What was it? Coffee maybe, forgot what it was. Toilets behind labelled palm trees, sore feet. Sit where old men once sat who were still good enough for some work in spite of sore feet.

We have payed $1000 \mathrm{KSH}$ in order to

commemorate the life of Baroness Karen Blixen, the talented Danish author, poet and farmer. Karen Blixen is the author of several books including the famous Out of Africa later documented into a movie with the same title. ${ }^{3}$

Her servants, whom she treated well, called her Memsabib, and she called them by their names. Each of them had a name, a single name. They had single stories, too. Yet she wrote about African people as people who resemble each other. Children resemble each other when you watch them at play, siblings. Africans, she said, are free and close to nature and they will always remain that way and make their own decisions. They even decide when to die, like a little boy who died because he wanted to. This is a boy in one of her stories, Kitosch, who is beaten to death.

Ngugi Wa Thiong'o (1993) wrote about it and deemed this and other texts of hers unbearably racist, colonial, maternalistic. At this point in the visit, one is unbelievably grateful that he wrote this, as sad as it may be.

Karen Blixen returned to live with her mother at the family home in Rungstedlund Denmark where she spent the rest of her days. It was at this stage in her life that she seriously started her literary career. Her first book 'Seven Gothic Tales['] was published in America 1934, where it received the 'Book of the month' award. 'Out of Africa' was published in 1937. Karen continued to write a number of successful books and articles right up to the time of her death in $1962 .{ }^{4}$

An interesting perspective, too. All the experiences, emotions, romance, love, dangers, safaris, coffee plantation bankruptcies, open-air hair-washings and infidelities were achieved before she left, were incorporated while in Africa (Kenya), before she went back to Europe (the North). There, her writing took place. Raewyn Connell writes about the South as 
a site where data mining takes place in typical colonial and postcolonial settings, while theory-making and writing is done in the North. Africa, in these texts and in the museum, is presented as a source of something that is needed for the production of great colonial literature. It provides the raw materials - adventure, transgression. But the making of literature itself takes place elsewhere. And this is decisive; it is not so much simply the text itself as its production that reveals its ultimate coloniality.

Even though there is much in these texts that reveals irony and the subversion of hegemonic norms, a subtle critique of the British colonial society, there is never any unequivocal passage where colonial power inequalities are addressed as what they were and are - violent and ruinous. Importantly, the writer, the voice or narrator she creates, and her texts have previously been understood as hybrid, as being both European and African, male and female, North and South (Brantly, 2013). However, such hybridity emerges from performance, not the daily practice from which text and voice emerge. And this is precisely what becomes conceivable once the author's life is made visible as a simulacrum in the form of a Hollywood love story, which itself triggers the creation of yet another simulacrum, namely the remade house and museum. The ways in which the museum, the book and the film speak to each other, and visitors and guides get involved in this complex relationship, reveal how roles are already scripted, and how inescapable they seem. Suddenly, Blixen's insinuated hybridity and interest in the colonized is revealed as colonial mimicry. The mimicry is such that the ruinous and violent colonial actor turns into the colonized as a hero and deified figure (Roque, 2020), yet performing this very different role only for some time, not more. There, at the fringes of the city and of everything, where lions could (then) be seen, one could be somebody else, could live a different life.

Looking back on her life in Africa, Karen Blixen felt 'that it might altogether be described as the existence of a person who had come from a rushed and noisy world into a still country'. ${ }^{5}$

'Karen is a way of life', Danielle de Lame (2010) notes in Grey Nairobi, and the museum and its grounds are deceptive in suggesting that there might have been any real hybridity. Not hybridity emerging from a white body immersing into what Blixen calls the essence of an entire continent, but something more substantial, less exoticist, less Orientalist. But Karen, de Lame writes, remains remote and exquisite, like the segregated flowers in the museum garden.

Hybridity is, we assume, something that has to do with the North rather the South. This might astound some: certainly, the colonized world has always been seen as hybrid; the colonial towns of the tropics are hybrid (and vibrant, don't forget vibrant; warm and moist, too - this is how hybridity is made to grow best), Creole languages are hybrid, postcolonial societies are hybrid, and so on. But these are hybridities that are 
constructed as being salient (and therefore in need of explanation) by means of positioning them in opposition to an imagined orderly (nonhybrid) North. The nation state is orderly, as are democracy, Northern road systems and classrooms - they are not hybrid.

The Southern (African, and therefore Kenyan) players that feature in Blixen's text, the film and the museum never offer any mooring for hybridity. They are fundamentally defined, fixed and named. The servant Kamande Gitura is forever seated on that stone bench, is forever just Kamande Gitura (even though he might well have had other names, simply by being a whole social being), a cook, a Kikuyu. Nothing mixes or mingles here. A man like him would not have been portrayed as a partner of a woman from Europe, for example, and he alone, without any link to the writer, would perhaps not have been interesting enough as a figure in a film, text or museum that 'commemorate[s] the life of Baroness Karen Blixen, the talented Danish author, poet and farmer', would never have been more than just a faithful piece of decoration. He is part of the staffing needed in heritaging. Did he have a pseudonym? Were there nicknames? Not unless they were chosen by the European chronicler, we assume.

But Blixen had names, and used pseudonyms - abundantly so. She is hybrid, and she claims authorship over her hybridity, challenging Northern bourgeois order. This is not inflicted upon her, by colonial dislocation or by disruption, but chosen and performed. And we simpletons wonder a bit: is this the same Blixen as Tania, who wrote this book, which inspired the film? Yes. And of course we always thought that. Easy to guess, actually. But then: 'I find it difficult, however, to accustom myself to Karen Blixen's many names, e.g. Isak Dinesen and Pierre Andrezél besides the American synonym Meryl Streep', Søren Rasmussen writes, in The Greatest Safari. And the website of the Karen Blixen Museum in Denmark offers a dozen or so more names to add. This is hybrid, this is enigmatic. Self-authorship in order to dissolve. A photograph of her taken by Beaton bears her signature on its back: 'With love, Tania'. This is her German nom de guerre and she writes it on her very British portrait. She is said to have been subversive, against British upper-class etiquette.

At the museum, we are offered photographs of her. Few of them show much of her connection with Kenya (Africa). Images that illustrate her career as a writer abound. She is shown with many celebrities of her time, and all we see on these images are White people. White people who write and read about Africa, as we do, as tourists do, as one just does.

But what captures our eyes more than the Whiteness of the place and its imagery is its dryness. This is a very dry place. Dry things to see, dryness in what we hear. Also the dried-out body in these photographs: this woman is so thin. Eyes too large. We look for explanations: after syphilis, she depended on laxatives, some of her biographers observe. Became addicted to laxatives. Couldn't eat; probably anorexia. Died of malnutrition. Beaton's portrait is hard to bear. Did he care? 
Automummification is an extreme form of asceticism. In religious contexts it was, or maybe is, not considered as an act of suicide, but as reaching a form of enlightenment.

And mummified language?

The absence of embodied presences is something we find distressing. All these stories about love and relationships, and then not a single trace of language to make this happen. In the film, the other woman, whose lover dies as well, the other BLACK woman, remains mute. In Karen's house we are reminded of her piercing eyes, her quiet stare. Here, too, nothing speaks. Linguistic drought. The volumes of Out of Africa are on display, in all the different languages into which it was translated, framed book covers, written explanations on objects, even on pots and boxes. Everything is labelled and defined, in English, sometimes Danish, everywhere. But no interaction takes place: this is language that does not reach out. It does not speak.

What we can hear is the pump behind the toilet, after flushing. Blixen was addicted to laxatives. The tour guides working today explained what needs to be explained outside, speaking with soft voices, sitting on green plastic chairs that stand on the immaculate lawn. Inside, it is tidy, orderly, quiet. How do we revive this dead matter?

What remains: language conserved, inarticulate and remote. A Hollywood movie, its image politics and Eurocentric storyline. Signboards of Pentecostal churches on the road we took coming here. What is the reason for visits to such places?

\section{Notes}

(1) See https://hookedonhouses.net/2010/03/22/karen-blixens-house-in-out-of-africa/ (accessed 12 August 2020).

(2) See https://www.kenyamuseumsociety.org/karen-blixen-museum/ (accessed 12 August 2020).

(3) See https://www.kenyamuseumsociety.org/karen-blixen-museum/ (accessed 12 August 2020).

(4) See https://www.kenyamuseumsociety.org/karen-blixen-museum/ (accessed 12 August 2020).

(5) See https://www.kenyamuseumsociety.org/karen-blixen-museum/ (accessed 12 August 2020). 


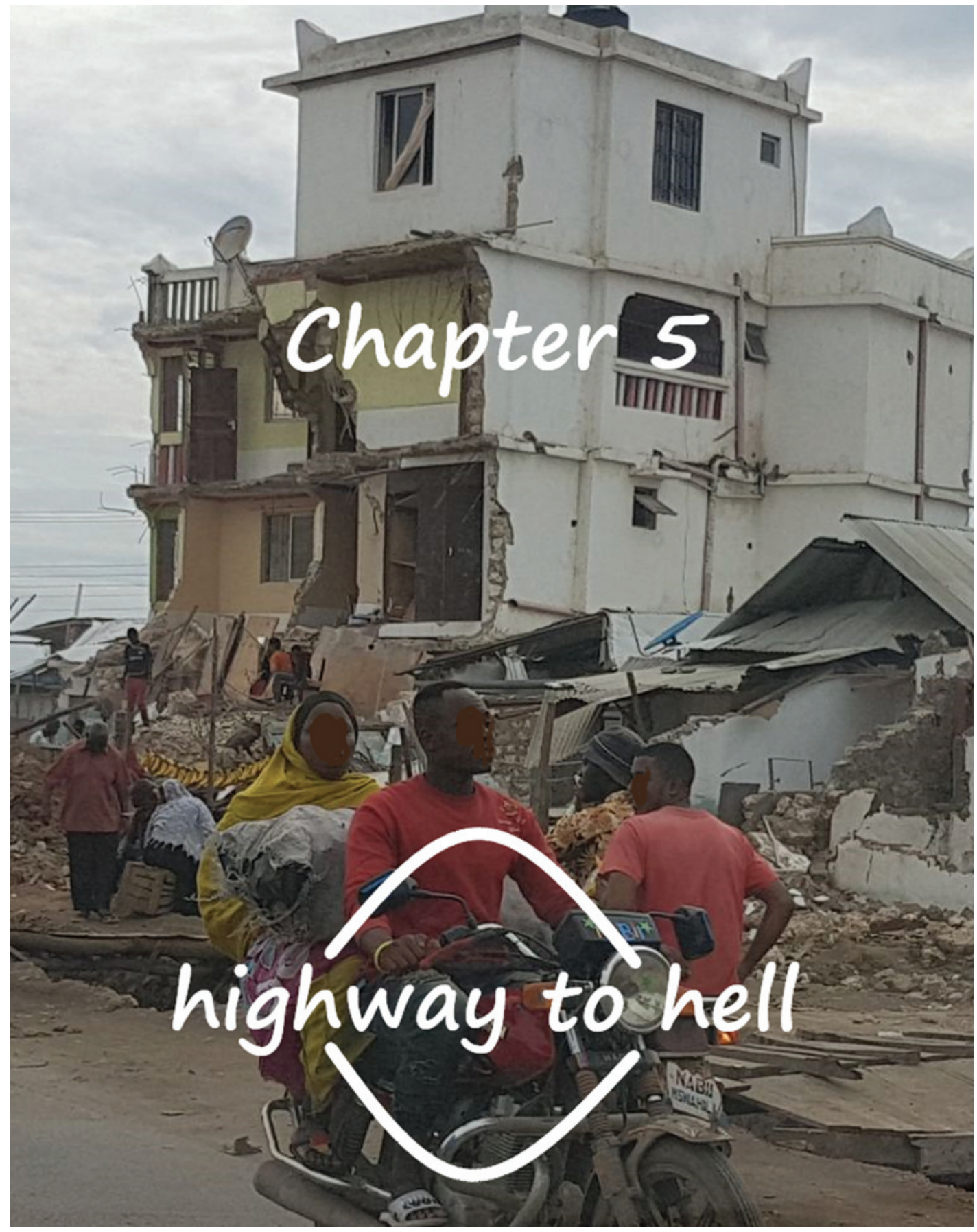


